\title{
The relative importance of impacts from climate change vs. emissions change on air pollution levels in the 21 st century
}

\author{
G. B. Hedegaard ${ }^{1,2, *}$, J. H. Christensen ${ }^{1}$, and J. Brandt ${ }^{1}$ \\ ${ }^{1}$ Aarhus University, Department of Environmental Science, Roskilde, Denmark \\ ${ }^{2}$ Danish Climate Center, Danish Meteorological Institute, Copenhagen, Denmark \\ *now at: Center for Climate and Environmental Research, Lund University, Lund, Sweden
}

Correspondence to: J. Brandt (jbr@dmu.dk)

Received: 21 June 2012 - Published in Atmos. Chem. Phys. Discuss.: 19 September 2012

Revised: 3 March 2013 - Accepted: 10 March 2013 - Published: 2 April 2013

\begin{abstract}
So far several studies have analysed the impacts of climate change on future air pollution levels. Significant changes due to impacts of climate change have been made clear. Nevertheless, these changes are not yet included in national, regional or global air pollution reduction strategies. The changes in future air pollution levels are caused by both impacts from climate change and anthropogenic emission changes, the importance of which needs to be quantified and compared. In this study we use the Danish Eulerian Hemispheric Model (DEHM) driven by meteorological input data from the coupled Atmosphere-Ocean General Circulation Model ECHAM5/MPI-OM and forced with the newly developed RCP4.5 emissions. The relative importance of the climate signal and the signal from changes in anthropogenic emissions on the future ozone, black carbon (BC), total particulate matter with a diameter below $2.5 \mu \mathrm{m}$ (total $\mathrm{PM}_{2.5}$ including $\mathrm{BC}$, primary organic carbon $(\mathrm{OC})$, mineral dust and secondary inorganic aerosols (SIA)) and total nitrogen (including $\mathrm{NH}_{\mathrm{x}}+\mathrm{NO}_{\mathrm{y}}$ ) has been determined. For ozone, the impacts of anthropogenic emissions dominate, though a climate penalty is found in the Arctic region and northwestern Europe, where the signal from climate change dampens the effect from the projected emission reductions of anthropogenic ozone precursors. The investigated particles are even more dominated by the impacts from emission changes. For black carbon the emission signal dominates slightly at high latitudes, with an increase up to an order of magnitude larger, close to the emission sources in temperate and subtropical areas. Including all particulate matter with a diameter below $2.5 \mu \mathrm{m}$ (total $\mathrm{PM}_{2.5}$ ) enhances the dominance from emissions change. In contrast, total nitrogen $\left(\mathrm{NH}_{\mathrm{x}}+\mathrm{NO}_{\mathrm{y}}\right)$ in parts of
\end{abstract}

the Arctic and at low latitudes is dominated by impacts of climate change.

\section{Introduction}

All meteorological parameters do effect the chemistry and physics of the atmosphere either directly or indirectly through various chemical and physical interactions and feedback mechanisms. Since the last IPCC report (Pachauri and Reisinger, 2007) it has become clear that climate change is already taking place and will continue in the future, which means that the global, regional and local meteorological conditions will change in the future. Furthermore, emissions will change due to population growth and technology evolution. In the early and mid-1970s, the first global pollutant problems were identified. The Arctic haze were (re-)discovered in the early 1970s (Wilkening, 2011) and after some years it became clear that it has its origin from Asian and European pollution. Since then, air pollution has no longer been a local or regional problem, but has turned into a global problem and in response, national and international air pollution legislations were formulated and enforced. New legislations are formulated every year in order to prevent future atmospheric pollution levels from amplifying, or alternatively, to clean up past and present pollution in the purpose of returning to cleaner atmospheric conditions. Therefore large changes in both climate conditions and emission levels and distributions are to be anticipated, and together these will determine future air pollution levels. 
Future changes in emissions of air pollutants will impact air pollution levels on a global, regional and local scale. Additionally, changes in the future climate conditions will significantly effect the global, regional and local air pollution levels. Most recent studies have concentrated on the signal from climate change (Langner et al., 2005; Murazaki and Hess, 2006; Hedegaard et al., 2008, 2011, 2012) and only a few have compared the climate and the anthropogenic emission signals over limited areas in the US (Tagaris et al., 2007; Wu et al., 2008b; Pye et al., 2009; Racherla and Adams, 2009).

In this study we hypothesize that, in some areas, climate change can have a significant impact on future air quality relative to the impacts from changes in future emissions. The signals from changes in climate conditions and emissions might cancel out, dampen or even amplify each other depending on the sign of the individual contributions. We aim to estimate the size and sign of the impact from changes in climate and emissions relative to both each other and to the total predicted change due to both drivers together. The entire Northern Hemisphere has been analysed; however, it should be emphasized that nobody knows the future and that this study is to be considered as a sensitivity study and a first step in the direction of quantifying the relative importance of impacts from climate change vs. emission change in this century. In the following section the model setup and scientific method are described. In Sect. 3, the output from the climate model is described. In Sect. 4 the results of ozone, black carbon (BC), $\mathrm{PM}_{2.5}$ (including primary emitted mineral dust, black carbon (fresh and aged), organic carbon, and the secondary formed particles $\mathrm{H}_{2} \mathrm{SO}_{4}, \mathrm{NO}_{3}^{-}, \mathrm{NH}_{4} \mathrm{NO}_{3}, \mathrm{NH}_{4} \mathrm{HSO}_{4}$ and $\left.\left(\mathrm{NH}_{4}\right) 2 \mathrm{SO}_{4}\right)$ and total nitrogen $\left(\mathrm{N}_{\mathrm{x}}+\mathrm{NO}_{\mathrm{y}}\right)$ are presented and discussed. The current model setup does not include Secondary Organic Aerosols (SOA). Finally, the conclusions are summarised in Sect. 5.

\section{Model setup and method}

In this study the Danish Eulerian Hemispheric Model (DEHM) is driven by six-hourly meteorology input simulated by the coupled Atmosphere-Ocean General Circulation Model ECHAM5/MPI-OM and forced with the newly developed RCP4.5 emissions (Clarke et al., 2007; Smith and Wigley, 2006; Wise et al., 2009). The fate of 58 chemical species and 9 classes of particulate matter has been simulated for the decades of the 1990s and the 2090s in order to quantify the fluctuation in air pollution levels due to climate change and changes in emissions levels, respectively. The current model version includes black carbon (BC), primary emitted organic carbon (OC), mineral dust and secondary inorganic aerosols (SIA); however, secondary organic aerosols (SOA) are not included in this model version. The performance of the total model system with ECHAM5/MPI-OM model coupled to the DEHM model system has been thor- oughly tested in earlier studies (Hedegaard, 2007; Hedegaard et al., 2008, 2011, 2012; Geels et al., 2012). DEHM is an Eulerian atmospheric chemistry transport model and a thorough model description can be found in Brandt et al. (2012) and references therein.

The coupled atmosphere-ocean model ECHAM5/MPIOM consists of an Atmospheric General Circulation Model ECHAM5 (Roeckner et al., 2003, 2006) and the ocean-seaice model MPI-OM (Marsland et al., 2003). The specific simulation used in the climate model for this experiment is forced with the SRES A1B scenario (Nakicenovic et al., 2000) and details about the parameterization and aerosol effect for this particular model version can be found in May (2008). It should be noted that the forcing from emission A1B only applies to the projected meteorology. The anthropogenic emissions that feed into the chemical transport model DEHM is based on the newly developed RCP4.5 emission scenarios (Clarke et al., 2007; Smith and Wigley, 2006; Wise et al., 2009). The representative concentration pathway (RCP) stabilizes at radiative forcing of $4.5 \mathrm{~W} \mathrm{~m}^{-2}$ after year 2100. The emission data are global and have a resolution of $0.5^{\circ} \times 0.5^{\circ}$. One emission data set is provided for each decade, which in this case means that for the period 19901999 , the emissions are represented by the RCP emissions for the year 2000; for the period 2090-2099 we use the emission data set from year 2100. In contrast, the biogenic emission of isoprene is calculated dynamically in the model according to the GEIA natural VOC emission model (Guenther et al., 1995; Zare et al., 2012). Other naturally emitted VOCs, such as terpenes, are not yet included in the model.

Several simulations have been carried out with different combinations of meteorology and emissions in order to study the relative importance of impacts from climate change and impacts from changes in anthropogenic emissions. The decade from 1990-1999 (denoted met1990s) and from 20902099 (denoted met2090s) are investigated to give a first estimate of the changes during the 21 st century. As a reference period, the 1990s decade has been simulated with meteorology predicted by the ECHAM5/MPI-OM model for the same period (1990-1999) and constant 2000 emission. The reference simulation is from now on denoted as $x($ met $1990 \mathrm{~s}$, emis2000), where $x$ is the concentration or deposition of a specific chemical specie, such as ozone.

The climate change signal (CS) relative to the reference period is given by

$\mathrm{CS}=\frac{x(\text { met2090s, emis2000) }-x(\text { met1990s, emis2000) }}{x(\text { met1990s, emis2000), }}$

where $x$ is a given parameter (such as ozone concentration or nitrogen deposition) and $x$ (met2090s, emis2000) represent the level of the given parameter $x$ due to future meteorology for the period 2090-2099 and constant 2000-level emissions derived from the RCP4.5 emission database. This means that in Eq. (1) above, the signal from climate change is found by 
keeping the anthropogenic emissions constant at a presentday level and changing the meteorology.

- For CS > 0: The given parameter increase due to climate change

- For $\mathrm{CS}=0$ : The given parameter does not change due to climate change

- For $\mathrm{CS}<0$ : The given parameter decrease due to climate change

Similarly, the signal from changes in emissions is identified by a simulation with present-day meteorology 19901999 and scenario emissions for the year 2100 , denoted as $x$ (met1990s, emis2100).

$\mathrm{ES}=\frac{x(\text { met1990s, emis2100) }-x(\text { met1990s, emis2000) }}{x(\text { met1990s, emis2000) }}$

The signal from emission change (ES) for a given parameter $x$ is obtained by keeping the meteorology constant and force the simulation with future year-2100 level emissions based on the RCP4.5 emission scenario.

- For ES > 0: The given parameter increase due to emission change

- For ES =0: The given parameter does not change due to emission change

- For ES $<0$ : The given parameter decrease due to emission change

Finally, the total signal (TOTS) or best guess of the future is based on future meteorology 2090-2099 and scenariopredicted emissions for the year 2100 and this is denoted as $x$ (met2090s, emis2100).

TOTS $=\frac{x(\text { met2090s, emis2100 })-x(\text { met1990s, emis2000) }}{x(\text { met1990s, emis2000) }}$

It should be noted that the changes are non-linear for most species due to the non-linear nature of the atmospheric chemistry (except for the primary particles), e.g., $\mathrm{CS}+\mathrm{ES} \neq \mathrm{TOTS}$. The signal from climate change and the signal from emission change do not add up to the total signal from climate and emission change.

In order to quantify the size of the signals relative to one another, three fractions have been set up:

The climate signal relative to the total signal is given by

$\frac{\mathrm{CS}}{\mathrm{TOTS}}=\frac{x(\text { met2090s, emis } 2000)-x(\operatorname{met} 1990 \mathrm{~s}, \text { emis} 2000)}{x(\operatorname{met} 2090 \mathrm{~s}, \mathrm{emis} 2100)-x(\operatorname{met} 1990 \mathrm{~s}, \mathrm{emis} 2000)}$

The emission signal relative to the total signal is given by

$\frac{\mathrm{ES}}{\mathrm{TOTS}}=\frac{x(\text { met1990s, emis2100 })-x(\operatorname{met} 1990 \mathrm{~s}, \text { emis} 2000)}{x(\operatorname{met} 2090 \mathrm{~s}, \mathrm{emis} 2100)-x(\operatorname{met} 1990 \mathrm{~s}, \mathrm{emis} 2000)}$
The climate signal relative to the emission signal is given by

$\frac{\mathrm{CS}}{\mathrm{ES}}=\frac{x(\text { met2090s, emis } 2000)-x(\operatorname{met} 1990 \mathrm{~s}, \text { emis } 2000)}{x(\text { met1990s, emis2100) }-x(\operatorname{met} 1990 \mathrm{~s}, \text { emis} 2000)}$

From Eqs. (4) and (5) the size of the climate and emission signal relative to the the total change including non-linear effects can be determined. Furthermore, Eq. (6) gives the size of the climate signal relative to the emission signal. Whether the two signals amplify or dampen each other can be seen from the climate signal (Eq. 1) and the emission signal (Eq. 2), respectively. This means:

- For CS/ES =1: The climate and emission signal is of equal size and sign and the sign can be determined from Eqs. (1) and (2).

- For CS/ES > 1: The size of climate signal is larger than the size of the emission signal and the effects are either both positive (increasing) or both negative (decreasing) and therefore result in an amplified effect on a given concentration or deposition $(x)$.

- For CS/ES $<1$ : The emission signal dominates and either the climate signal or the emission signal is negative. The sign of the two signals can again be determined from Eqs. (1) and (2) (see Fig. 4a and b in the case of ozone concentration).

\section{Meteorology by ECHAM5/MPI-OM}

In the following, the output from the ECHAM5 climate simulation used to drive the DEHM model is described. The temperature, humidity and precipitation are direct outputs from the ECHAM5 simulation, whereas the mixing height is derived from energy balance considerations and the radiation is calculated from the cloud cover (for details see Hedegaard, 2007). The ECHAM5 climate simulation used in this study were a part of the 4th IPCC Assessment Report (AR4) multimodel ensemble study. In the current simulation, the global temperature is predicted to increase by $3.0^{\circ} \mathrm{C}$ by the end of the 21 st century, and $4.3^{\circ} \mathrm{C}$ by the end of the 22nd century, both relative to the period 1971-2000 (May, 2008). This increase is a little higher than the average value $\left(2.7^{\circ} \mathrm{C}\right.$ and $3.4^{\circ} \mathrm{C}$, respectively) predicted by the multi-model ensemble following the SRES A1B scenario in the AR4 (Meehl et al., 2007). However, it is well within the standard deviation of the IPCC AR4 multi-model ensemble by the end of the 21st century.

The model setup is the same as in Hedegaard et al. (2011, 2012) and details about the temperature, humidity and global radiation can be found therein. The following illustrations of the meteorological output are limited to display the precipitation frequency and the mixing height of the 1990 and 2090 


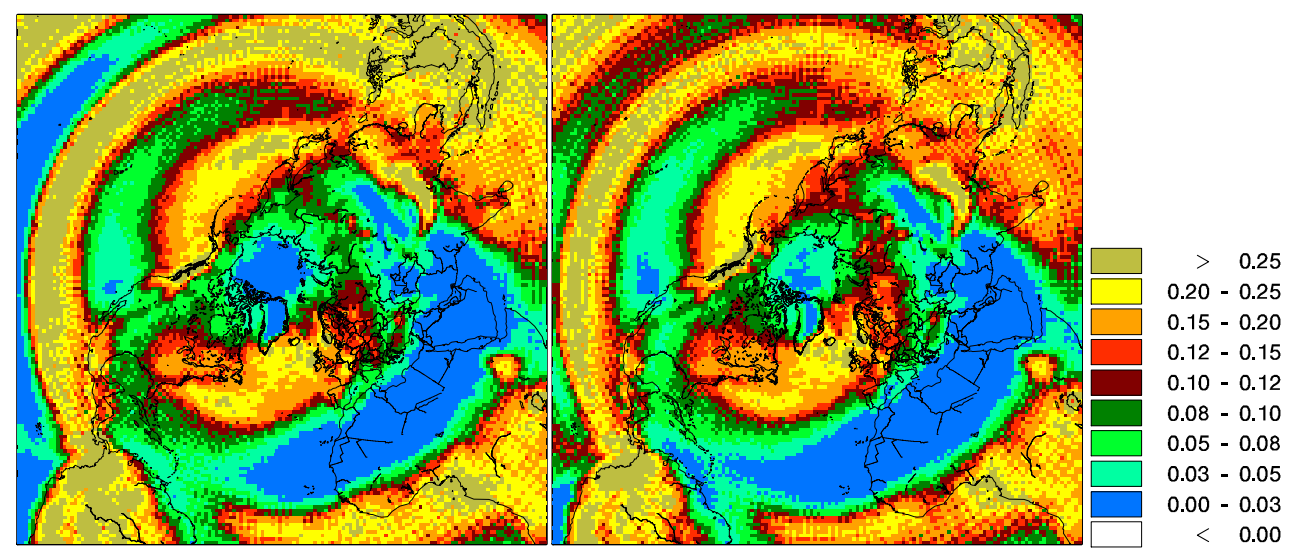

(a) 1990s annual mean precipitation frequency

(b) 2090s annual mean precipitation frequency
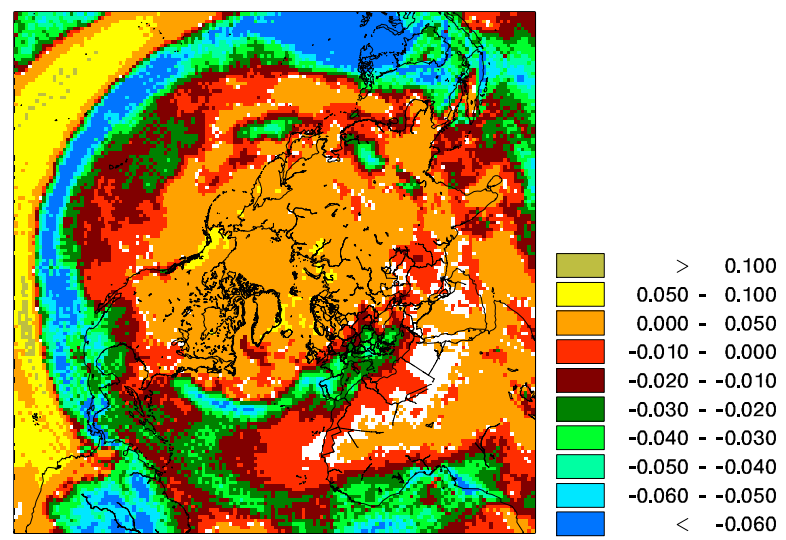

(c) Difference in annual mean precipitation frequency (2090s-1990s)

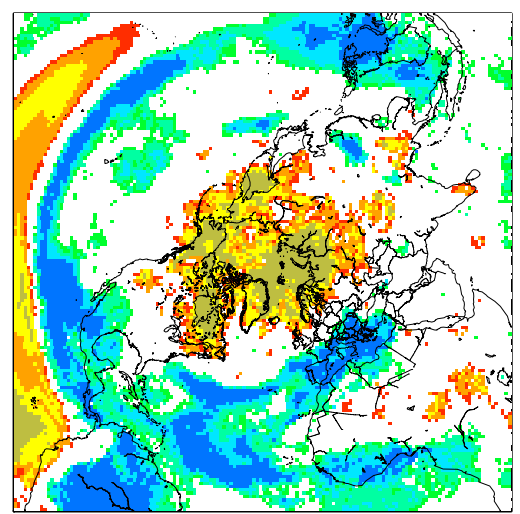

(d) Significance of the difference

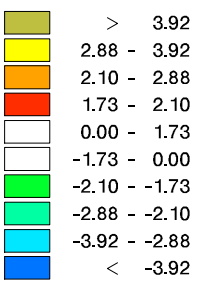

Fig. 1. Annual mean precipitation frequency: defined as a fraction between 0 and 1 , the threshold value for precipitation in a given six-hour interval is $1 \mathrm{~mm}$. (a) shows the annual mean precipitation frequency during the 1990s decade and (b) during the 2090s decade. In (c) the difference between the 2090s and the 1990s is shown, and finally (d) illustrates the significance of the difference between the two decades, white colours indicate no significant change and the threshold value for significance is set to $10 \%$.

decades. In Fig. 1 the annual mean precipitation frequency of the two decades are considered, together with the absolute change between these decadal mean values and the significance of these changes using a Student's $t$ test (Spiegel, 1992).
The precipitation frequency is defined by a threshold value of $1 \mathrm{~mm}$ for precipitation occurring in a given six-hour interval and is defined as a fraction between 0 and 1 , where 1 indicates precipitation in a given grid cell in a given six-hour time interval. The choice of $1 \mathrm{~mm}$ threshold value is based on the 


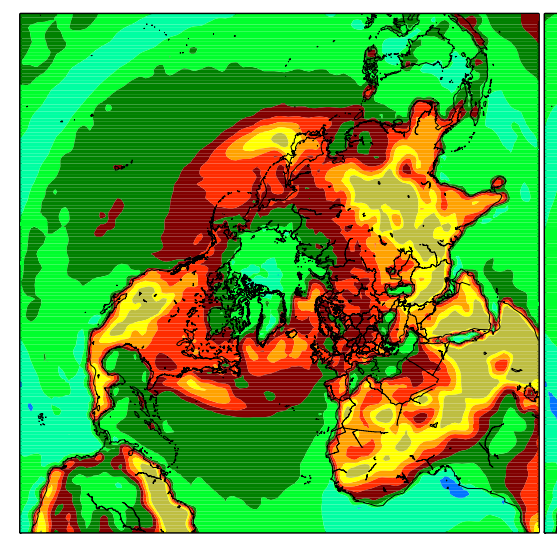

(a) 1990s annual mean mixing height in $\mathrm{m}$

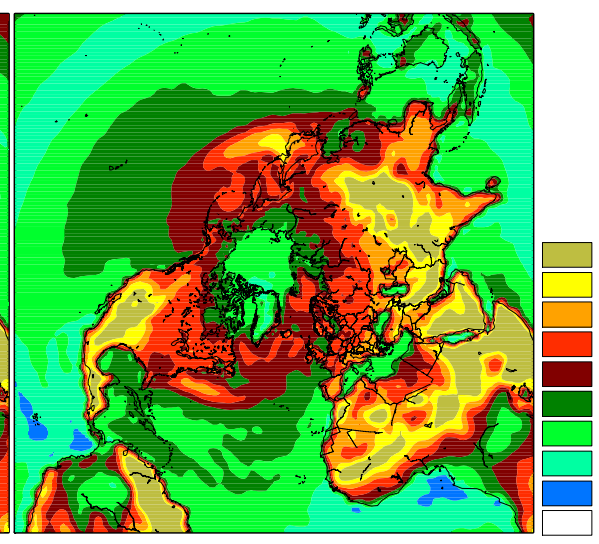

(b) 2090s annual mean mixing height in $\mathrm{m}$

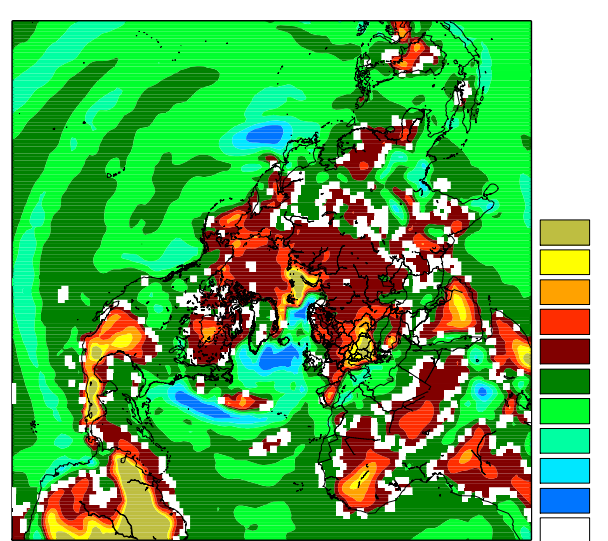

(c) Difference in annual mean mixing height in $\mathrm{m}$ (2090s-1990s)

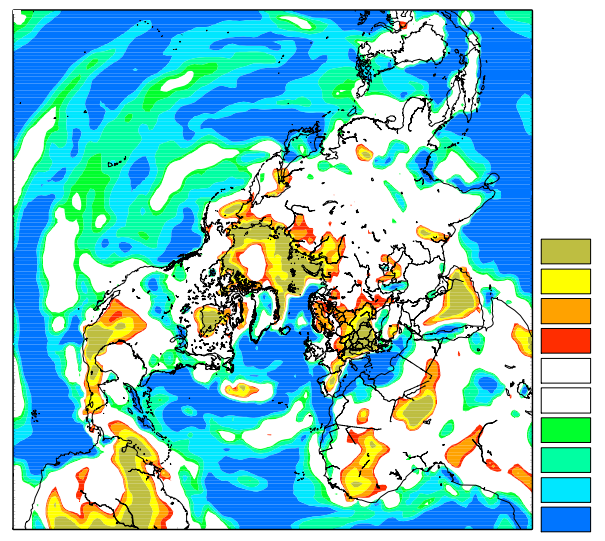

(d) Significance of the difference

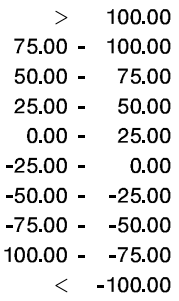

$\begin{array}{rr}> & 3.92 \\ 2.88- & 3.92 \\ 2.10- & 2.88 \\ 1.73- & 2.10 \\ 0.00- & 1.73 \\ -1.73- & 0.00 \\ -2.10- & -1.73 \\ -2.88- & -2.10 \\ -3.92 & -2.88 \\ < & -3.92\end{array}$

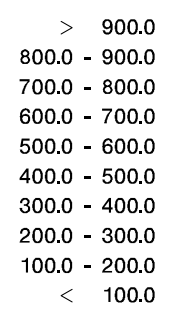

$<100.0$

.

. 


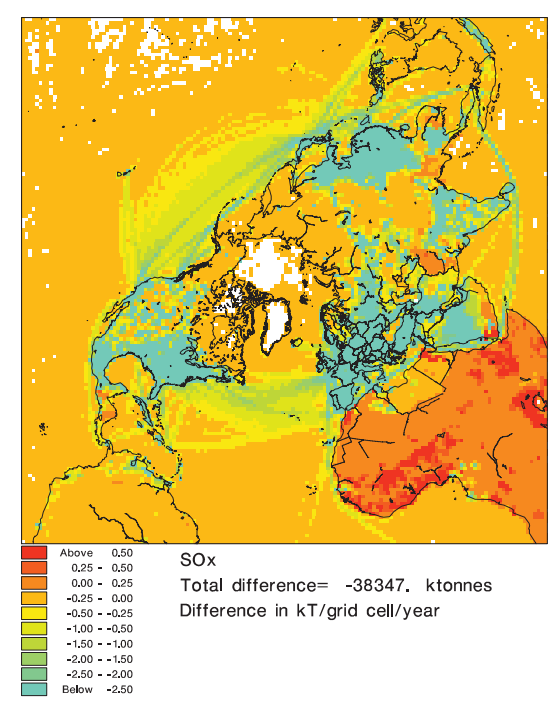

(a) Difference in $\mathrm{SO}_{\mathrm{x}}$ emissions; 2100-2000

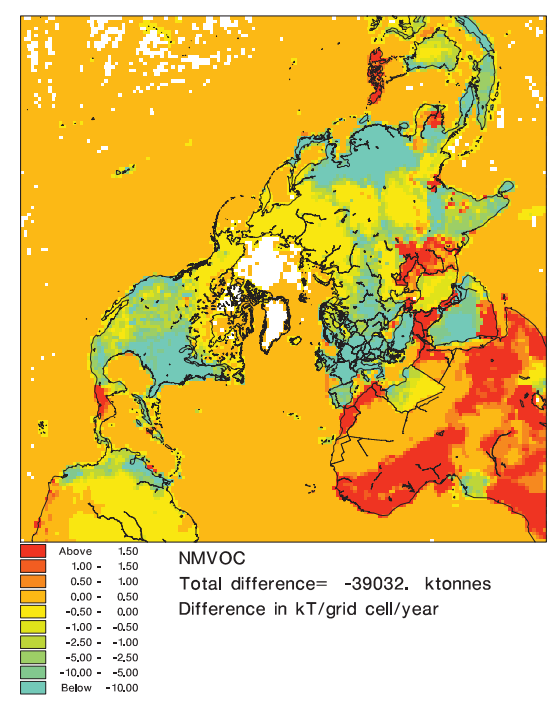

(c) Difference in NMVOC emissions; 2100-2000

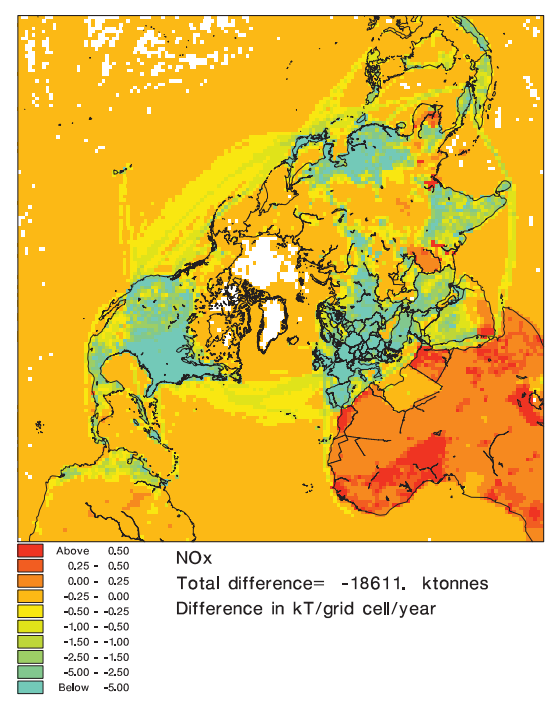

(b) Difference in $\mathrm{NO}_{\mathrm{x}}$ emissions; 2100-2000

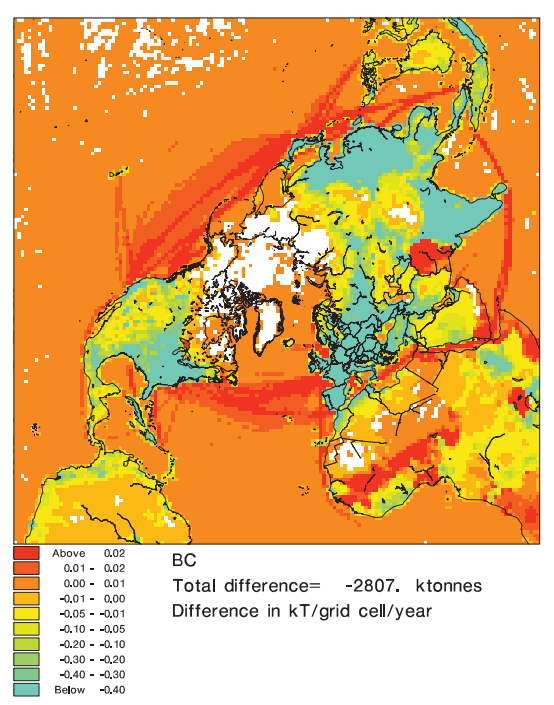

(d) Difference in BC emissions; 2100-2000

Fig. 3. Difference in anthropogenic emissions between year 2100 and year 2000 (2100 minus 2000) in the Northern Hemisphere projected with RCP4.5 for (a) $\mathrm{SO}_{\mathrm{x}}$, (b) $\mathrm{NO}_{\mathrm{x}}$, (c) $\mathrm{NMVOC}$, and (d) $\mathrm{BC}$.

is projected to increase north of about $60^{\circ} \mathrm{N}$ and decrease significantly in the subtropical parts of the Pacific and Atlantic Ocean, the Caribbean, Mexico and the central South America and in Western Africa.

Figure 2 shows the mixing height in $\mathrm{m}$. The mixing height is calculated from an energy balance equation for the internal boundary layer according to the methods described in Christensen (1997). Figure 2 is given similar to the precipitation frequency, where (a) shows the 1990s decadal mean mixing height, (b) the 2090s decadal mean, (c) the difference in m, and (d) the significance of this difference. In southeastern
Europe, the mixing height is projected to increase from $50 \mathrm{~m}$ to above $100 \mathrm{~m}$, which gives a relative change of app. $20 \%$. Small increases $(0-25 \mathrm{~m})$ are found in general over Eurasia and the Arctic Ocean. In Mexico, the Caribbean and in central South America, the mixing height is also projected to increase in the range of $50 \mathrm{~m}$ to above $100 \mathrm{~m}$. In general the mixing height is projected to decrease over marine areas. 


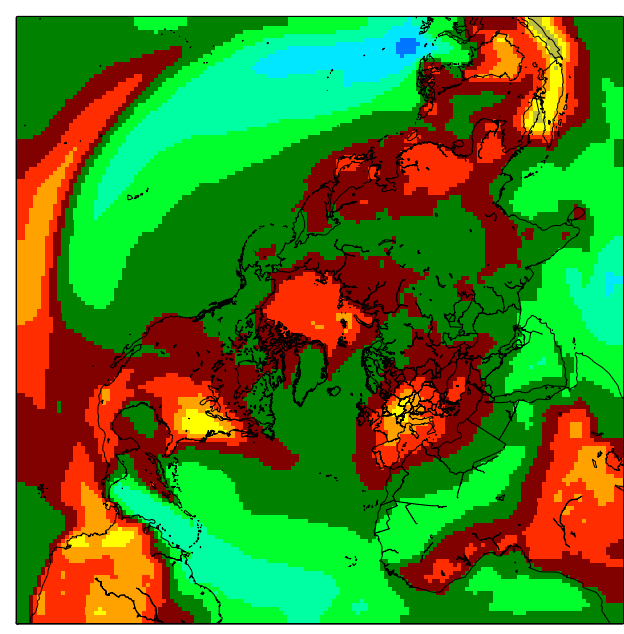

(a) $\mathrm{O}_{3}$ : Climate signal (see eq. 1)

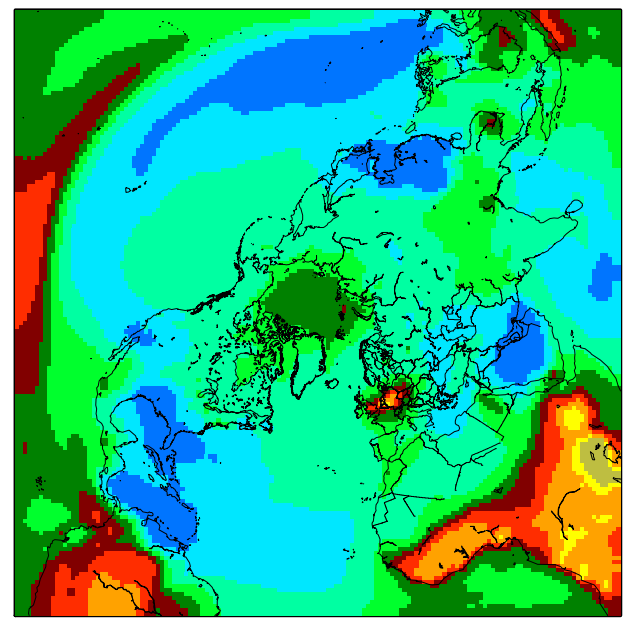

(c) $\mathrm{O}_{3}$ : Total signal (see eq. 3)

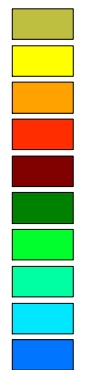

$\begin{array}{rr}> & 0.20 \\ 0.15 & -0.20 \\ 0.10 & -0.15 \\ 0.05 & -0.10 \\ 0.00 & -0.05 \\ -0.05 & -0.00 \\ -0.10- & -0.05 \\ -0.15 & --0.10 \\ -0.20- & -0.15 \\ < & -0.20\end{array}$

(e) Legend for a,b,c (fraction)

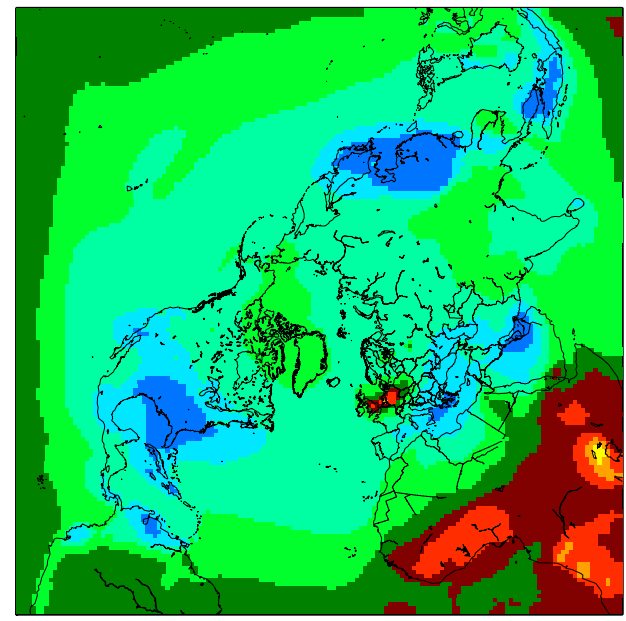

(b) $\mathrm{O}_{3}$ : Emission signal (see eq. 2)

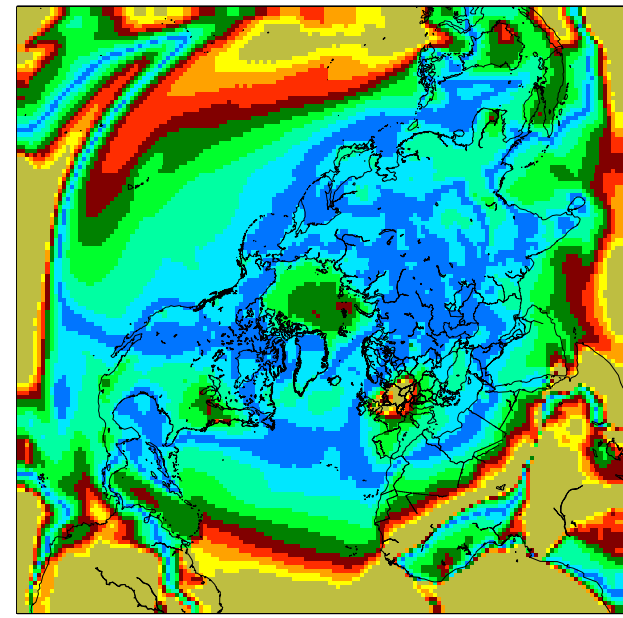

(d) Climate signal/Emission signal (see eq. 6)

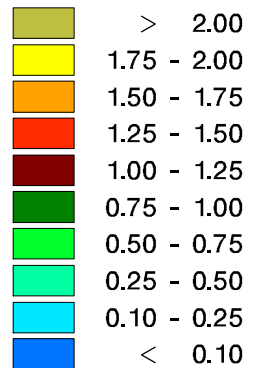

(f) Legend for d (fraction)

Fig. 4. $\mathrm{O}_{3}$ : The signal from (a) future climate change, (b) future emission change, (c) the total change on the surface ozone concentration due to changes in both future climate and emissions, and (d) the climate signal relative to the emission signal. The climate signal is simulated with constant year 2000 emissions and ECHAM5 meteorology. The signal from changes in the anthropogenic emissions is simulated with projected RCP4.5 emissions and 1990s meteorology.

\section{Results and discussion}

In the following the results of ozone $\left(\mathrm{O}_{3}\right)$, black carbon (BC), and total $\mathrm{PM}_{2.5}$ (including primary emitted mineral dust, black carbon (fresh and aged), organic carbon, and the sec- ondary formed particles $\mathrm{H}_{2} \mathrm{SO}_{4}, \mathrm{NO}_{3}^{-}, \mathrm{NH}_{4} \mathrm{NO}_{3}, \mathrm{NH}_{4} \mathrm{HSO}_{4}$ and $\left.\left(\mathrm{NH}_{4}\right)_{2} \mathrm{SO}_{4}\right)$ and total nitrogen (sum of $\mathrm{NO}_{\mathrm{y}}$ and $\mathrm{NH}_{\mathrm{x}}$ ) are displayed and discussed. 


\subsection{Projected changes in emissions}

In Fig. 3 the difference in anthropogenic emissions between year 2100 and year 2000 (2100 minus 2000) in the Northern Hemisphere projected with RCP4.5 is given for $\mathrm{SO}_{\mathrm{x}}, \mathrm{NO}_{\mathrm{x}}$, NMVOC (non-methane volatile organic compound), and BC. A general decrease in the hemispheric anthropogenic emissions are projected for all the shown species, however with some regional and continental differences. A relatively large decrease is seen in North America, Europe, India and eastern parts of Asia, while a rather large increase is taking place in Africa due to a projected economic growth in this region, according to the RCP4.5 scenario. Furthermore, an increase in emissions from the international ship traffic is foreseen due to an increase in the shipping transport in general.

\subsection{Ozone}

Figure 4 illustrates the changes in ozone surface concentration due to impacts of climate change and changes in the anthropogenic emissions between the 1990s and 2090s. In Fig. 4a the signal from climate change is displayed. The change in ozone concentration in this figure is solely due to climate change and the anthropogenic emissions have been kept constant at a 2000 level. The ozone concentration is projected to increase over the Arctic, the densely populated areas and the terrestrial tropics. Elsewhere the ozone concentration will decrease due to climate change alone.

The increase in the Arctic is likely to be due to increased transport of ozone from the source areas at lower latitudes in combination with reduced amount of sea ice in the future. $\mathrm{O}_{3}$ dry deposits more effectively to sea ice than to open water in the model, and decreased sea ice in the 2090s results in increased ozone in the Arctic air masses. Further increased import of ozone from higher layers can also explain the projected increase in ozone concentration due to climate change (Hedegaard et al., 2011, 2012).

In densely populated areas and over the tropics, the $\mathrm{NO}_{\mathrm{x}}$ and/or the VOC (volatile organic compound) level in general are high and the changed climate leads to enhanced productions of BVOCs (biogenic volatile organic compounds)and hence higher ozone levels over these areas. In the rest of the domain, the effect from increased water vapour in the atmosphere enhances ozone destruction, and this process dominates in the areas with lower $\mathrm{NO}_{\mathrm{x}}$ and VOC concentrations (for further details see discussion in Hedegaard et al., 2011, 2012).

Figure $4 \mathrm{~b}$ illustrates the changes in the ozone concentration due to changes in the anthropogenic emission between the two decades 1990s and 2090s. In this simulation, the meteorology has been kept constant according to the 1990s meteorology in order to isolate the signal from changed anthropogenic emissions. In most of the domain the emission signal is opposing the signal from climate change. The model estimates a decrease in the current ozone concentration in the order of $20 \%$ between the 1990s decade and 2090s decade, solely due to changes in the anthropogenic emissions of $\mathrm{NO}_{\mathrm{x}}$ and NMVOC, see Fig. 3. The tendency is different in parts of northwestern Europe. In the Benelux countries and the vicinity, the ozone concentrations are estimated to increase due to changes in the anthropogenic emissions. This is also the case in Sub-Saharan Africa.

The projected increase in ozone concentrations in the future in these areas can be explained by the applied emission inventory. The $\mathrm{NO}_{\mathrm{x}}$ emissions are general prescribed to decrease in the future according to the RCP4.5 emission scenario (www.iiasa.ac.at/web-apps/tnt/RcpDb). In the Benelux area the $\mathrm{NO}_{\mathrm{x}}$ emissions are also projected to decrease, however this area differs from the rest of the densely populated areas in the Northern Hemisphere. The largest density of $\mathrm{NO}_{\mathrm{x}}$ emissions over the largest area is found in Benelux and the surrounding areas. The area is characterized by urban area chemistry (high $\mathrm{NO}_{\mathrm{x}}$ area) and is at the same time very large. The ozone present in the urban area is used to convert the emitted $\mathrm{NO}$ to $\mathrm{NO}_{2}$, which is called the ozone titration effect or urban deficit (Fowler et al., 2008). This means that lowering the emissions of NO will increase the amount of ozone which alters chemical regime. Moreover, European $\mathrm{NO}_{\mathrm{x}}$ emissions are due to the regional legislations expected to be lowered significantly more than other other high $\mathrm{NO}_{\mathrm{x}}$ areas in the world.

In Africa a large increase in the future $\mathrm{O}_{3}$ concentration is found (Fig. 4b), which is explained by a large increase in the anthropogenic $\mathrm{NO}_{\mathrm{x}}$ emissions combined with generally high BVOC emissions in the tropics. About half of the global isoprene emissions originate from tropical broadleaf trees (Guenther et al., 2006) and the tropical meteorological conditions are highly conductive for isoprene emissions.

In Fig. $4 c$ the combined effect on the future ozone concentration from both changes in anthropogenic emissions and changes in the climate is shown, including any non-linear effect from the ozone chemistry included in the model. The ozone concentration decrease due to impacts from changes in both the future anthropogenic emissions and climate, except over the terrestrial Tropics and northwestern Europe (Benelux area).

Figure $4 \mathrm{~d}$ shows the relative importance of the two individual signals. This is illustrated by the fraction in (Eq. 6). Figure $4 \mathrm{~d}$ reveals that the increase in surface ozone concentration in the terrestrial Tropics and northwestern Europe are mainly due to the impacts of climate change. The climate signal dominates and is more than twice the size of the impact from changes in the anthropogenic emissions. Elsewhere the impacts from changes in anthropogenic emissions are dominating.

In the Arctic region a minor decrease in ozone concentration is projected due to a composite of two opposing signals. The impacts of climate change lead to a $5-10 \%$ increase (Fig. 4a) and the reduction in emission of ozone precursors implies a 5-10\% decrease (Fig. 4b). The total signal 


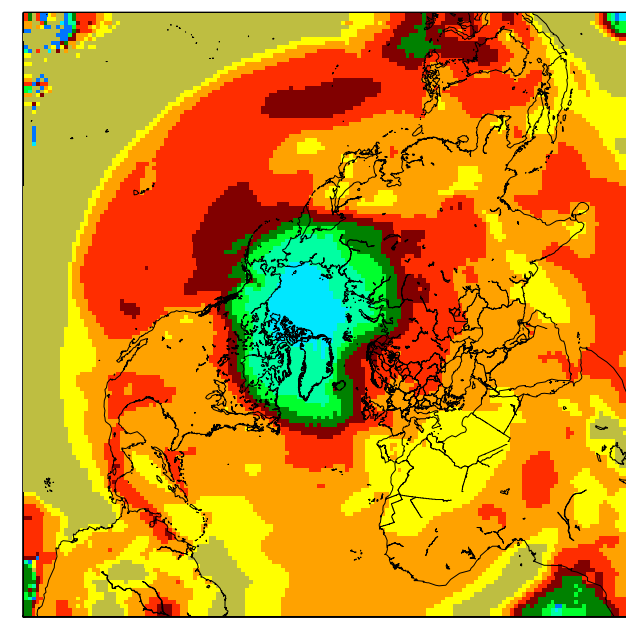

(a) BC: Climate signal (see eq. 1)

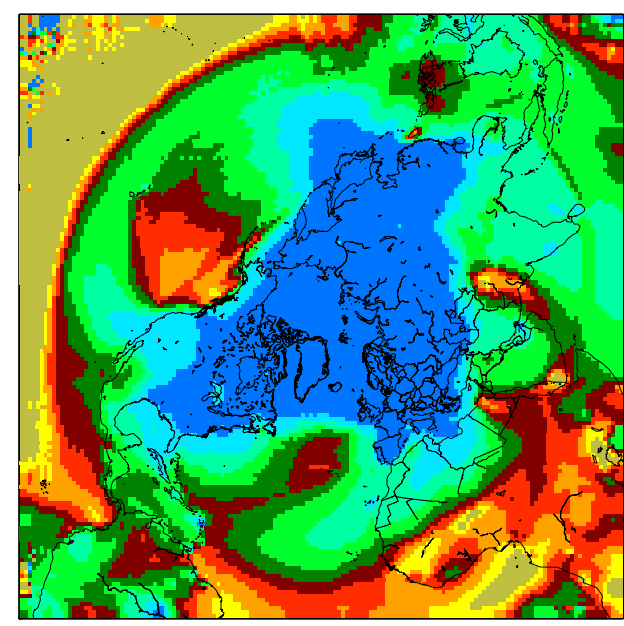

(c) BC: Total signal (see eq. 3)
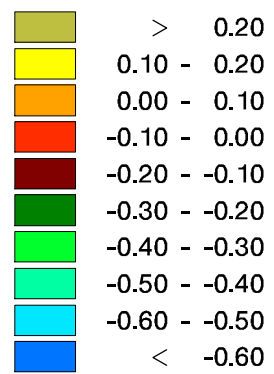

(e) Legend for a,b,c (fraction)

Fig. 5. Black carbon (BC): as Fig. 4, but for black carbon.

is displayed in Fig. $4 \mathrm{c}$ and shows a minor overall decrease in the Arctic by the end of the 21 st century. Figure $4 \mathrm{~d}$ shows that the climate signal is a little weaker than the emission signal (0.75-1.00).

In general the opposition of the two signals (impacts from climate change and impacts of changes in anthropogenic emissions) means that to obtain a certain reduction target in

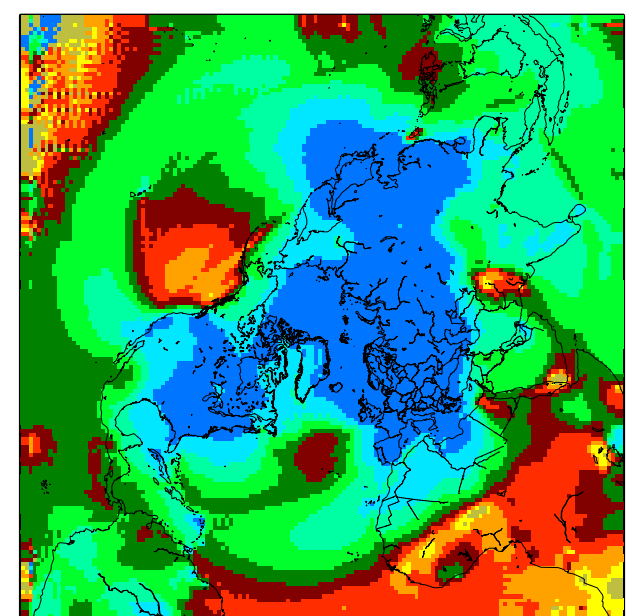

(b) BC: Emission signal (see eq. 2)

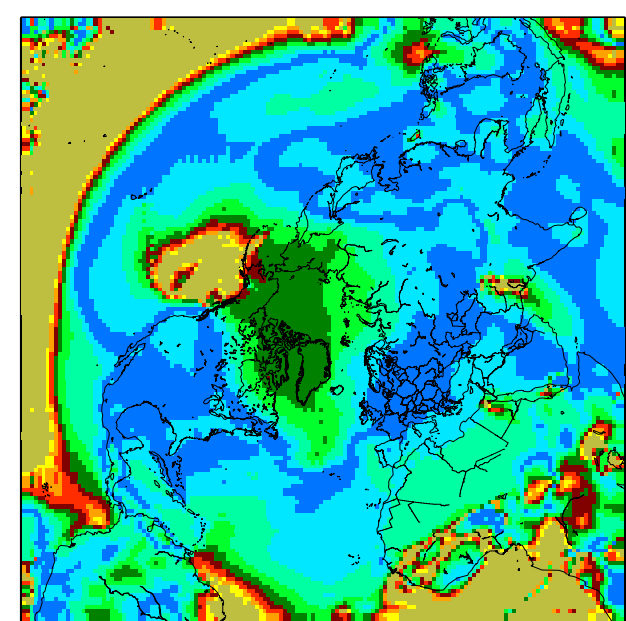

(d) Climate signal/Emission signal (see eq. 6)

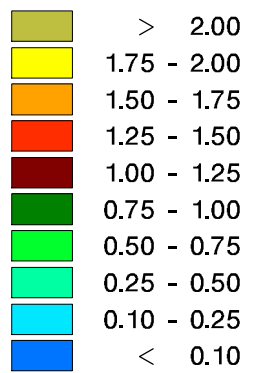

(f) Legend for d (fraction)

the future, additional reductions must be made in order to compensate from the opposing signal from climate change. This feature has in the literature been denoted "the climate penalty" (see e.g. Wu et al., 2008a). 


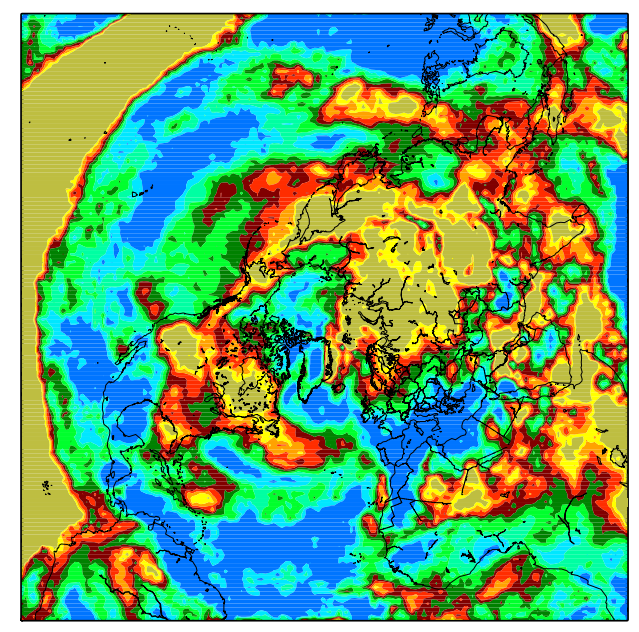

(a) BC: Relative changes in wet deposition in \%

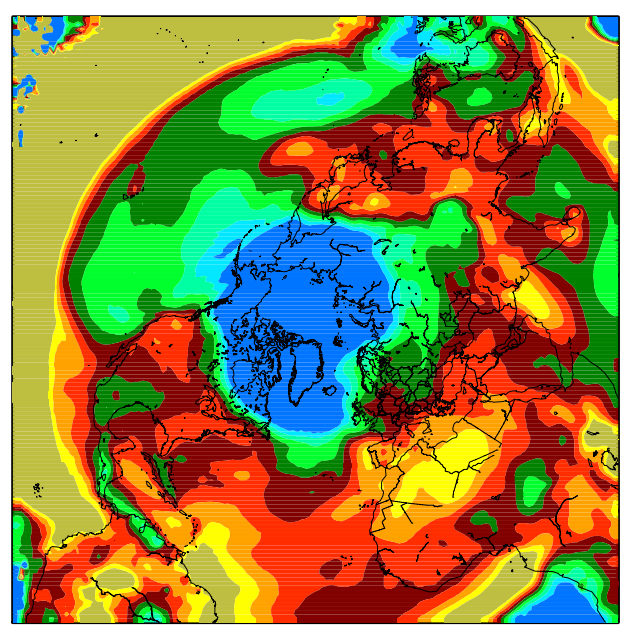

(c) BC: Changes in concentration in $\%$

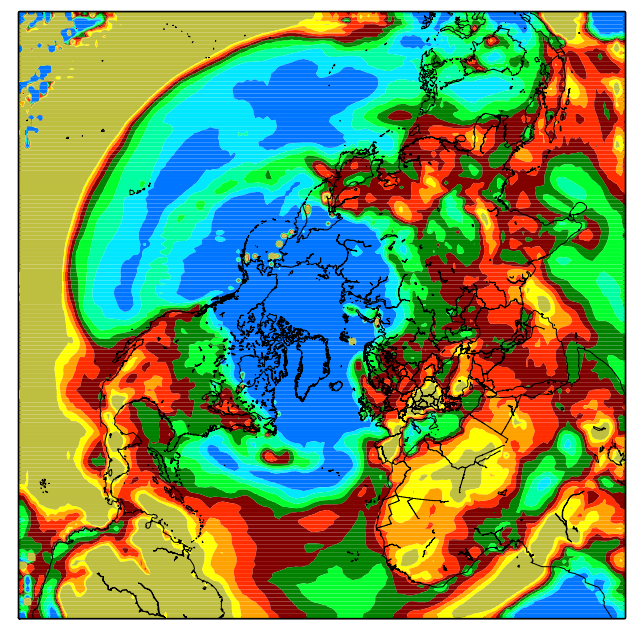

(b) BC: Relative Changes in dry deposition in $\%$

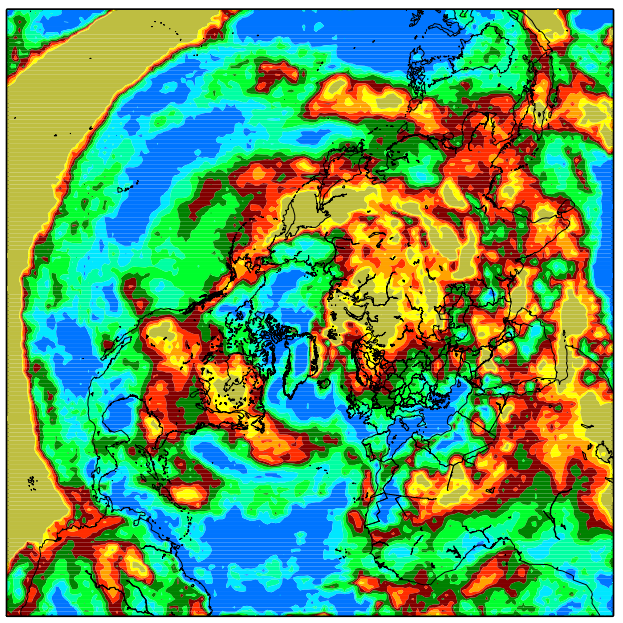

(d) BC: Relative Changes in total deposition in $\%$

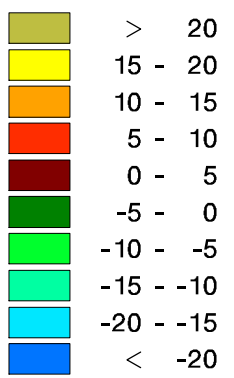

Fig. 6. Black carbon (BC): Relative change due to impacts of climate change in \% (2090s and 1990s). (a) wet deposition, (b) dry deposition, (c) concentration, and (d) total deposition.

\subsection{Black carbon and total $\mathrm{PM}_{2.5}$}

In Fig. 5 the change in black carbon (BC) surface concentration due to changes in (a) climate, (b) anthropogenic emissions, and (c) changes in both climate and anthropogenic emissions is shown. The latter is equal to the addition of (a) and (b), since BC is an inert tracer and does not react chem- ically with other species in the atmosphere. In Fig. 5d the climate signal is illustrated relative to emission signal.

The BC concentration is projected to decrease in the Arctic, in Scandinavia, over Eastern Europe and Russia and over large parts of the Pacific Ocean due to impacts of climate change (Fig. 5a). An increase is found nearly nowhere else. Since BC is an inert tracer in the model and the emissions are kept constant at a year 2000 level, only changes in the 
physical (e.g. meteorological) conditions can be the explanation of the projected changes.

In Fig. 6 the isolated effect from climate change on the BC (a) wet deposition, (b) dry deposition, (c) atmospheric concentrations and finally d) the total deposition is shown. The plots display the relative change in decadal mean values between the 1990s and the 2090s. At high latitudes and over the northeastern Pacific Ocean the atmospheric concentration of BC (Fig. 6c) is found to decrease significantly due to impacts of climate change.

In and south of the Mediterranean Sea, along the east coast of North America and Asia, and in general at low latitudes, the atmospheric concentration of $\mathrm{BC}$ is found to increase due to climate change. In the Mediterranean area there is a close relation between decreased precipitation frequency (Fig. 1) and decreased wet deposition (Fig. 6a) and increased atmospheric concentrations of BC. Over the North American and Asian east coast, on the contrary, the increased BC concentration in the air can be explained by a decrease in the mixing height (Fig. 2). Over the tropical terrestrial areas (Brazil/Sahara) the precipitation frequency decreases and hence the wet deposition decreases, which leads to increased atmospheric levels of BC.

Figure $5 \mathrm{~b}$ shows the relative contribution from the impact of changes in anthropogenic emissions on the atmospheric $\mathrm{BC}$ distribution according to the RCP4.5 emission scenario, see Fig. 3d. The contribution from emission change leads to a decrease in $\mathrm{BC}$ in the majority of the domain, though there are some differences in the size of the signal. Since the meteorology is kept constant (1990s level) in this simulation, to isolate the impact from changes in the emissions, only change in emissions size and spatial distribution can explain the pattern of Fig. $5 b$.

The majority of BC emissions stems from the transportation, industry, residential and biomass burning sectors and $\mathrm{BC}$ is therefore mainly emitted in and near the terrestrial areas. In the future these emissions are prescribed by the RCP4.5 scenario to decline significantly. In contrast, the emissions over the ocean are prescribed to increase. This increase originates from increased shipping activities in the remote marine areas, see www.iiasa.ac.at/web-apps/tnt/RcpDb for emissions from the individual sectors. In the current model setup the emissions from the aviation sector have not been included.

In Fig. $5 \mathrm{c}$ the total signal on BC from changes in both emissions and climate conditions is shown and further the climate signal relative to the emission signal, given in Fig. 5d. In general the concentration levels of $\mathrm{BC}$ are projected to be $30-60 \%$ lower in the future. In the tropics, a smaller decrease is found in the order $0-30 \%$ and in small parts of the tropics an increase is even found. The distinguished areas south of the Aleutian are strongly dominated by the signal from climate change. In this area, the climate signal opposes the projected increase (orange colour) due to changes in the anthropogenic emissions from ships. However, analysis of the absolute BC concentrations for the 1990s and the 2090s, due to both climate change and emission change, has shown that the distinct pattern south of the Aleutians is a result of small changes. In general it can be concluded that the changes due to impacts of climate change on an inert tracer like $\mathrm{BC}$ is small compared to the impacts from changes in the anthropogenic emissions which are absolutely dominating. The BC concentration will decrease due to a general reduction in the future $\mathrm{BC}$ emissions.

The total $\mathrm{PM}_{2.5}$ consists in the model of the sum of the following species: primary emitted mineral dust, black carbon (fresh and aged), organic carbon, and the secondary formed particles $\mathrm{H}_{2} \mathrm{SO}_{4}, \mathrm{NO}_{3}^{-}, \mathrm{NH}_{4} \mathrm{NO}_{3}, \mathrm{NH}_{4} \mathrm{HSO}_{4}$ and $\left(\mathrm{NH}_{4}\right) 2 \mathrm{SO}_{4}$. Secondary formed organic aerosols (SOA) are not included in the current model setup. Figure 7 shows the results for total $\mathrm{PM}_{2.5}$ similar to Fig. 5.

The impact of climate change alone (Fig. 7a) results in a decrease in the total $\mathrm{PM}_{2.5}$ at high latitudes (orange and red colours) and in a small increase (0-15\%) over a significant part of the Atlantic Ocean and in subtropical and tropical areas in general. A small decrease (0-15\%) is found over most of the subtropical Indian Ocean and Pacific Ocean. In contrast, the anthropogenic emissions act to decrease the future total $\mathrm{PM}_{2.5}$ concentration significantly in most of the domain except over Central Africa, where changes in anthropogenic emissions results in a small increase.

From Fig. $7 \mathrm{~d}$ it can be seen that the impact from changes in the total $\mathrm{PM}_{2.5}$ emissions dominate in the future. At high latitudes the overall signal from climate change and emissions change work in same direction and therefore amplify each other. In general the emission signal in future total $\mathrm{PM}_{2.5}$ concentration ranges from being twice the size of the climate signal to being an order of magnitude larger, which is also illustrated in the change in emissions of $\mathrm{SO}_{\mathrm{x}}$ and $\mathrm{BC}$ in Fig. 3a and $3 \mathrm{~d}$. In the case of $\mathrm{BC}$, only a slight dominance of the emission signal can be found in the Arctic region, increasing up to an order of magnitude higher, close to and downstream of the emission sources at mid-latitudes. The most important chemical process involved in climate change impacts the forming of secondary inorganic aerosols (SIA), compared to the inert tracer $\mathrm{BC}$, is the impact on $\mathrm{OH}$ concentrations from changes in $\mathrm{NO}_{\mathrm{x}}$ and NMVOC emissions. $\mathrm{OH}$ is very important for the lifetime of the primary emitted species; i.e. the speed they transform into SIA components. The chemistry involving climate change impacts on $\mathrm{OH}$ concentrations is given in detail in Hedegaard et al. (2012). Further, the changes in total sulfate concentration have been analysed (not shown) and the pattern is very similar to the projection of BC.

\subsection{Total N}

Total $N$ is defined by the sum of $\mathrm{NO}_{\mathrm{y}}\left(=\mathrm{NO}_{\mathrm{x}}+\mathrm{HONO}+\right.$ $\mathrm{PAN}+\mathrm{NO}_{3}^{-}+\mathrm{HNO}_{3}+$ organic nitrates $)$ and $\mathrm{NH}_{\mathrm{x}}\left(=\mathrm{NH}_{3}+\right.$ $\mathrm{NH}_{4}$ ). In Fig. 8 the individual contributions to the projected 


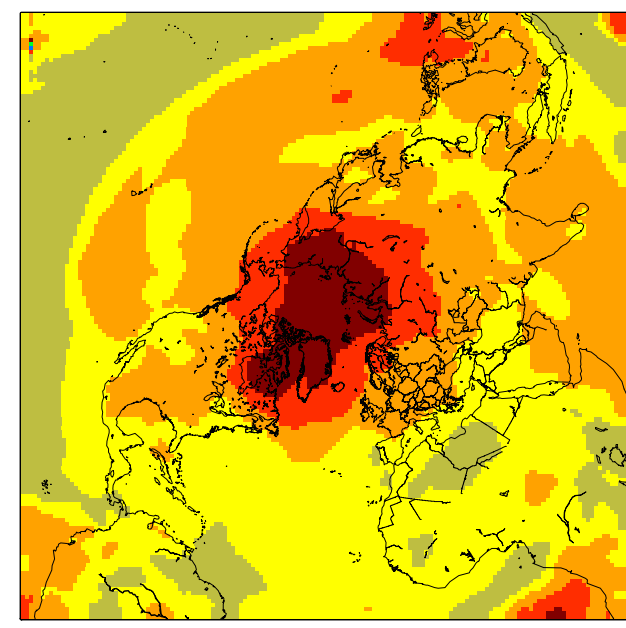

(a) $\mathrm{PM}_{2.5}$ concentration: Climate signal (see eq. 1)

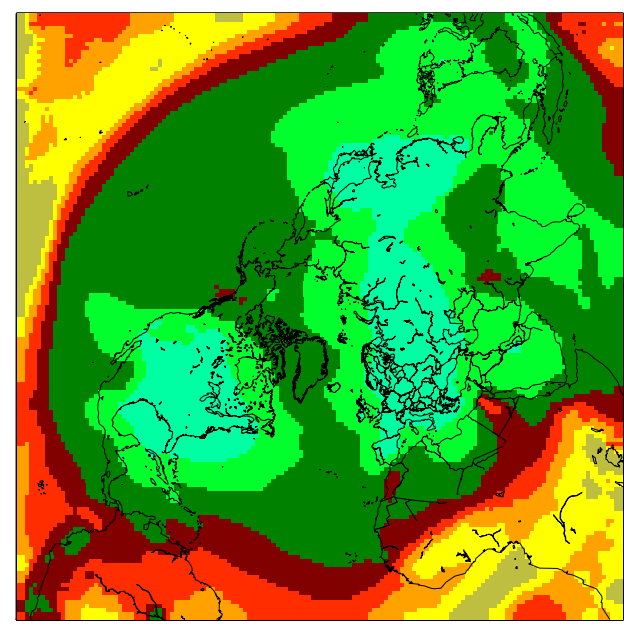

(c) $\mathrm{PM}_{2.5}$ concentration: Total signal (see eq. 3 )

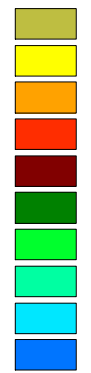
$>\quad 0.15$
$0.00-0.15$
$-0.15-0.00$
$-0.30--0.15$
$-0.45--0.30$
$-0.60--0.45$
$-0.75--0.60$
$-0.90--0.75$
$-1.05--0.90$
$<-1.05$

(e) Legend for a,b,c (fraction)

Fig. 7. Total $\mathrm{PM}_{2.5}$ : as Fig. 4 but for total $\mathrm{PM}_{2.5}$.

changes in total $N$ concentration are shown. This figure is displayed similarly to Figs. 4, 7 and 5. Since total $N$ contains both $\mathrm{NH}_{\mathrm{x}}$ and $\mathrm{NO}_{\mathrm{y}}$ the total $N$ distribution is dependent on chemical reactions. Therefore the total signal displayed in Fig. 8c is like in the case of $\mathrm{O}_{3}$ and the total $\mathrm{PM}_{2.5}$ is different from the addition of Fig. $8 a$ and $b$.

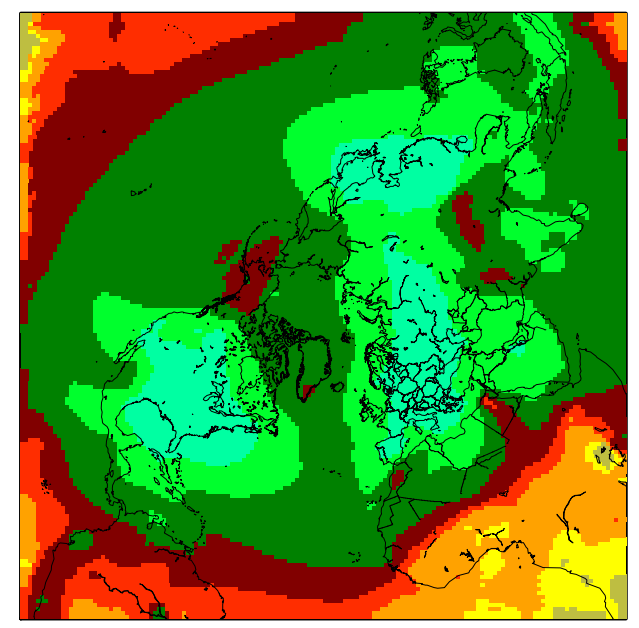

(b) $\mathrm{PM}_{2.5}$ concentration: Emission signal (see eq. 2)

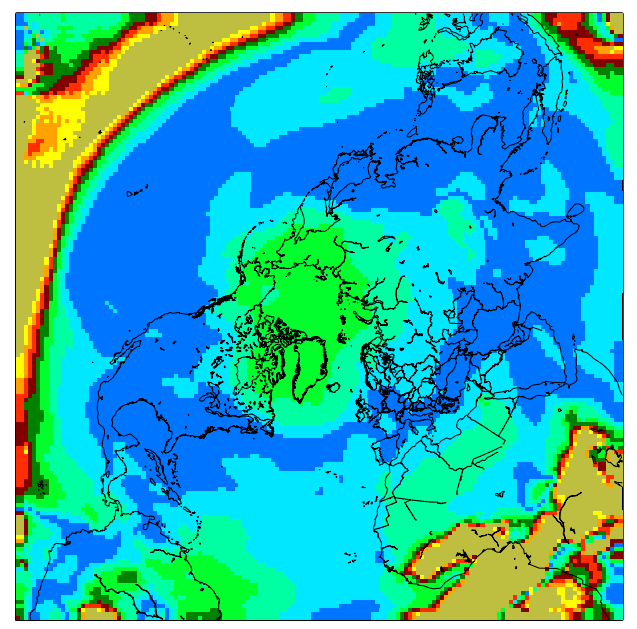

(d) Climate signal/Emission signal (see eq. 6)

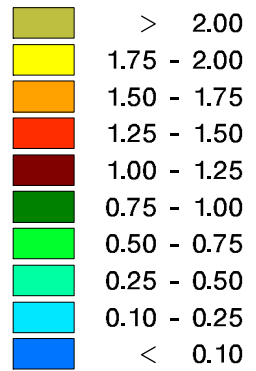

(f) Legend for d (fraction)

Changing the climate alone (Fig. 8a leads to a decrease in the nitrogen concentration in the future north of $\sim 50^{\circ} \mathrm{N}$, except over Europe, where a small increase $(0-10 \%)$ is found over Great Britain, Denmark, southern Sweden and the North and Baltic seas (Fig. 8a). At subtropical and tropical latitudes, the impacts from climate change gives rise to an increase in the $N$ concentration in the order $0-30 \%$ (Fig. 8a). 


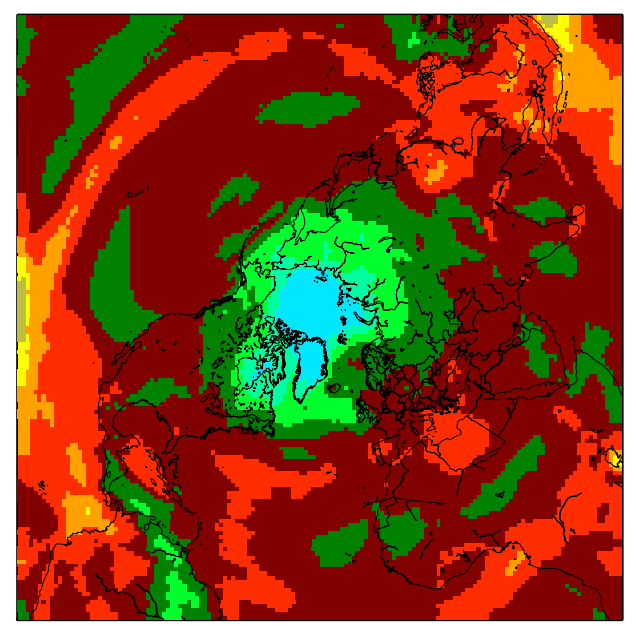

(a) Total $\mathrm{N}$ concentration: Climate signal (see eq. 1)

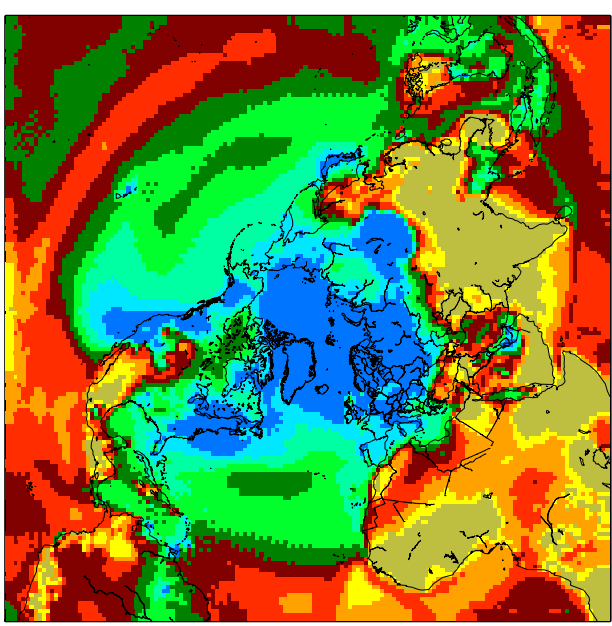

(c) Total $\mathrm{N}$ concentration: Total signal (see eq. 3 )

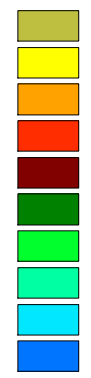

$\begin{array}{rr}> & 0.40 \\ 0.30- & 0.40 \\ 0.20- & 0.30 \\ 0.10- & 0.20 \\ 0.00- & 0.10 \\ -0.10- & 0.00 \\ -0.20- & -0.10 \\ -0.30- & -0.20 \\ -0.40- & -0.30 \\ < & -0.40\end{array}$

(e) Legend for a,b,c (fraction)

Fig. 8. Total nitrogen $(\mathrm{N})$ : as Fig. 4 but for total nitrogen N.

In Fig. $8 \mathrm{~b}$ the isolated effect of changed anthropogenic emissions is shown. Over Asia (except Siberia), Africa, Central America and the Southern US the impacts of changed emissions results in an increase above $30 \%$ in the atmospheric nitrogen concentration. Elsewhere the total nitrogen concentration is projected to decrease due to impacts of emission change alone, see also Fig. 3a. The decrease is largest

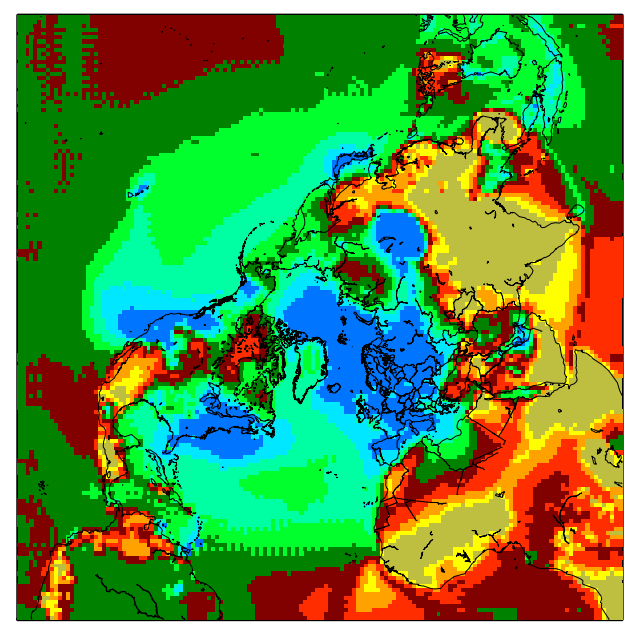

(b) Total $\mathrm{N}$ concentration: Emission signal (see eq. 2)

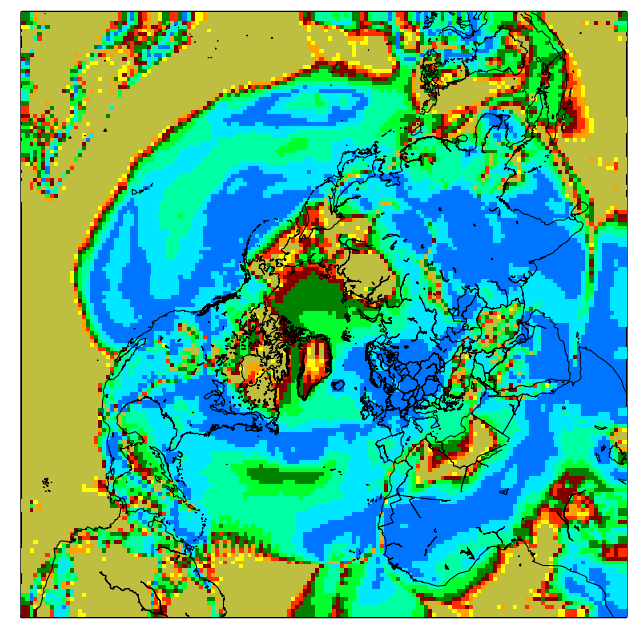

(d) Climate signal/Emission signal (see eq. 6)

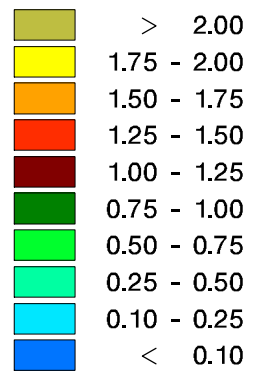

(f) Legend for d (fraction)

at high latitudes and is above $40 \%$ in the Arctic, over Europe, Japan and coastal areas of the US. The total changes, including both impacts from climate and emission change, are shown in Fig. 8c. The spatial pattern in Fig. 8c is very similar to the signal shown in Fig. 8b, except over the Pacific Ocean and South America. The impact from changed emission dominates Fig. 8b and from Fig. 8d it can be seen that 


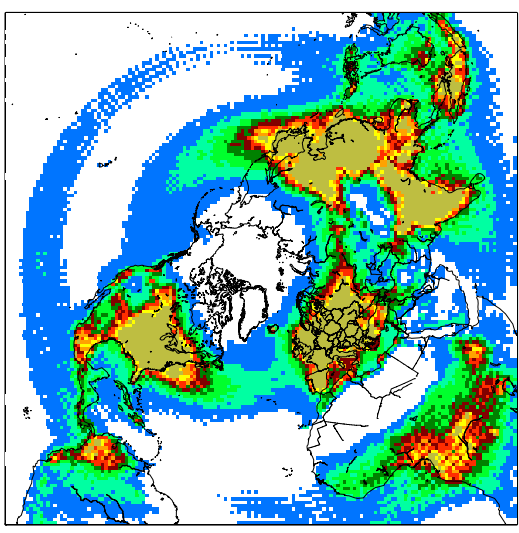

(a) $1990 \mathrm{~s}$ annual mean deposition of $\mathrm{N}$ in $\mathrm{mg} / \mathrm{m}^{2} /$ year

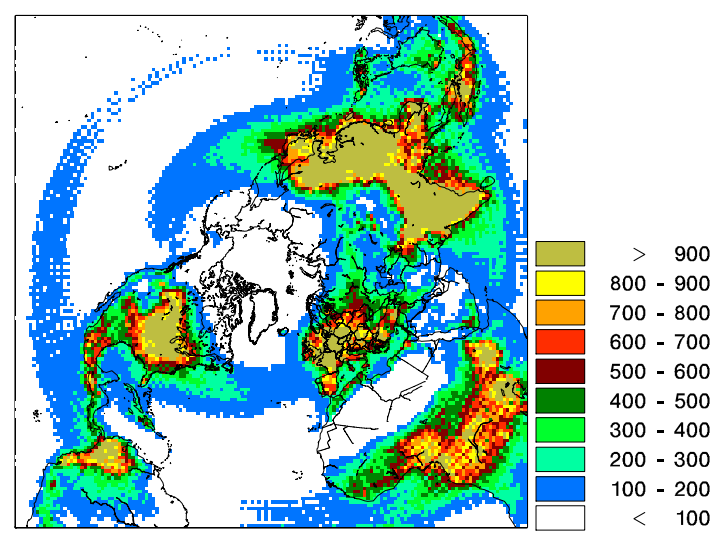

(b) $2090 \mathrm{~s}$ annual mean deposition of $\mathrm{N}$ in $\mathrm{mg} / \mathrm{m}^{2} /$ year
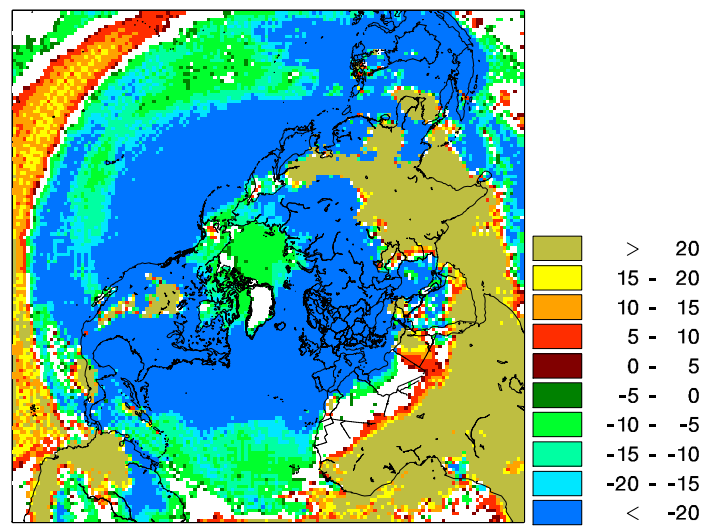

(c) Difference 2090s-1990s in $\mathrm{mg} / \mathrm{m}^{2} /$ year

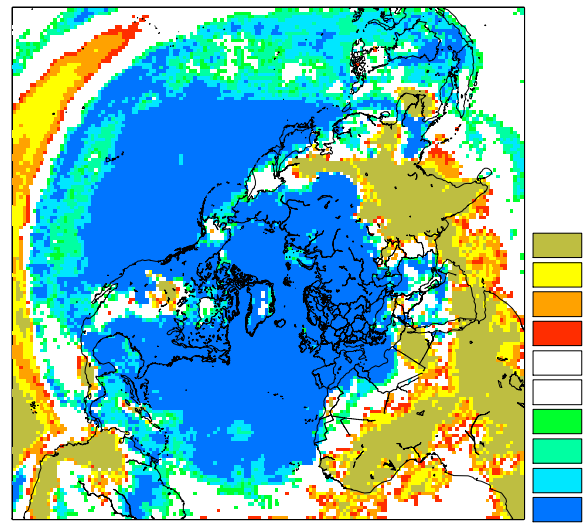

$$
\begin{array}{rr}
> & 3.92 \\
2.88- & 3.92 \\
2.10- & 2.88 \\
1.73- & 2.10 \\
0.00- & 1.73 \\
-1.73- & 0.00 \\
-2.10- & -1.73 \\
-2.88- & -2.10 \\
-3.92- & -2.88 \\
\hline & -3.92
\end{array}
$$

(d) Significance of the difference

Fig. 9. Total annual mean nitrogen deposition in $\mathrm{mg} / \mathrm{m}^{2} /$ year, displayed as Fig. 1 (including impacts from both climate change and emission change).

emission signal dominates in most areas ranging from being twice the size to an order of magnitude higher. In some regions the impacts from climate change is dominating, however this is mainly where both signals are very small (e.g. large part of the Tropics). In the terrestrial parts of the Arctic region (Northern Canada, Greenland and Siberia) the impacts from climate change is twice the size of the emission signal on future atmospheric total $N$ concentration.

Nitrogen deposition can have harmful effects on the marine and terrestrial ecosystems, hence the future nitrogen deposition has been analysed. The total (dry and wet) nitrogen deposition for the 1990s and 2090s decades is shown in Fig. 9, together with the difference (2090s and 1990s) and the 
significance of the difference. Over the densely populated areas of Asia, in Africa, and on the west coast of South America, the future nitrogen deposition is projected to increase by more than $20 \%$ (Fig. 9c). Elsewhere, the future total nitrogen deposition will decrease significantly. An exception is in the region of the Rocky Mountains and parts of China, where an increase is projected similar to the tropical region. Further, the areas in the Arctic (that from Fig. 8a are found to be controlled by the impacts of climate change) are areas with extremely low nitrogen concentrations (not shown) and hence the changes due to climate change are also very low. For a more detailed study of the projected change in atmospheric nitrogen deposition to the Baltic Sea towards 2020, see Geels et al. (2012)

The main interesting feature of the total $N$ is the change in deposition, which is dominated by changes in wet deposition. The impacts from climate change on the chemistry involving nitrogen species is neglected in this study, since we are assessing the total $N$. The chemistry only changes the concentrations from some nitrogen species to other nitrogen species and therefore the total $N$ is constant, considering the effects from chemistry alone. The main process is therefore the atmospheric transport of the nitrogen species and the atmospheric lifetime. One important process can have influence on the lifetime of the different chemical nitrogen species in the atmosphere and that is the dry deposition process. The dry deposition velocity is higher for, e.g. the gaseous compound $\mathrm{HNO}_{3}$ than for the nitrate particle, which is formed from $\mathrm{HNO}_{3}$. The same is true for e.g. $\mathrm{NH}_{3}$ and $\mathrm{NH}_{4}$. A detailed study of the climate change impacts on the nitrogen chemistry and change in the removal rate by dry deposition based on changes in the chemical balance is a full paper in itself and is beyond the scope of this study.

\section{Summary and conclusions}

So far only a few studies have concentrated on the relative importance of impacts from climate change and emission change and these studies have been limited to focus on smaller regions in the US. All three studies compare presentday with small periods around 2050, and the results are therefore not comparable to this study. Nevertheless, the overall conclusions are similar to the results found in this study.

In this study we used the Danish Eulerian Hemispheric Model (DEHM) driven on meteorological input from the coupled Atmosphere-Ocean General Circulation Model ECHAM5/MPI-OM and forced with the newly developed RCP4.5 emissions. The relative importance of the climate signal and the signal from changes in anthropogenic emissions on the future $\mathrm{O}_{3}, \mathrm{BC}$, total $\mathrm{PM}_{2.5}$ and total $N$ (sum of NOy and $\mathrm{NH}_{\mathrm{x}}$ ) has been determined.

The changes in anthropogenic emissions dominate in general over the signal from climate change. However in some cases the signal from climate change opposes the signal from the prescribed emission reductions, which implies that to obtain a certain reduction target in the future, additional reductions must be made in order to compensate for the opposing signal from climate change. This feature is known as "the climate penalty" (see e.g. Wu et al., 2008a).

Specifically, the ozone concentration over the Arctic area is found to decrease only a little in the future due to impact from both climate change and changes in the emission. Prescribed reduction of the ozone precursors in the source areas implies a significant decrease in the Arctic in the future. In contrast, the impacts from climate result in a significant increase, which is a little weaker than the decrease due to emissions reductions that minimize the overall effect to a minor decrease in the future Arctic ozone concentration.

In northwestern Europe it was found that future $\mathrm{NO}_{\mathrm{x}}$ reductions result in a rise in the ozone concentration due to the extreme $\mathrm{NO}_{\mathrm{x}}$ emission density in this area. This means that future air pollution control policies have to account for the amplified impact from climate change in order to reach a specific reduction target. This implies that emissions of VOCs also need to be considered as well in order to reduce both ozone and $\mathrm{NO}_{\mathrm{x}}$ levels in the future in northwestern Europe.

Compared to $\mathrm{O}_{3}$, the investigated particles are even more dominated by the impacts from emission changes. For BC, the emission signal dominates slightly at high latitudes, increasing up to an order of magnitude larger, close to the emission sources at temperate and subtropical areas. The total $\mathrm{PM}_{2.5}$ are similar to the $\mathrm{BC}$ concentration dominated by changes in emissions in most of the domain. The signal from changes in anthropogenic emissions ranges from being twice the size of the climate signal to being an order of magnitude larger than the climate signal for the total $\mathrm{PM}_{2.5}$ concentration.

In contrast, the atmospheric total nitrogen concentration is in parts of the Arctic and at low latitudes is dominated by impacts of climate change. In the terrestrial parts of the Arctic region (northern Canada, Greenland and Siberia) the impacts from climate change is twice the size of the emission signal on future atmospheric total $N$ concentration. In general, the impact from changed emissions dominates and is in some areas (e.g. over Europe) up to an order of magnitude higher than the signal from climate change.

The current work is to be considered as a sensitivity study. Nevertheless, it is the most comprehensive study so far, quantifying the impacts of climate change vs. anthropogenic emission change. Further, the new emission inventory RCP 4.5 has been used and the model domain covers the entire Northern Hemisphere. The current results indicate that impacts of climate change in general have less importance in the overall future concentration levels compared to anticipated changes in future anthropogenic emissions. Although there are certain regions for the different chemical species (e.g. ozone in the Arctic, northwestern parts of Europe and Africa) where the impacts from climate change on future air, pollution levels need to be accounted for in order to reach 
a certain reduction level. On the other hand, the results also show that for certain areas, the future emission reductions might be less strict, if certain limit values have to be reached, since the climate change impacts induce further decreases in the concentrations of particulate matter, as well as in the deposition of nitrogen in specific regions.

Acknowledgements. This work was partly funded by the Centre for Energy, Environment and Health (CEEH), financed by The Danish Strategic Research Program on Sustainable Energy under contract no 2104-06-0027 (www.ceeh.dk) and by the University of Copenhagen. Both institutions are acknowledged for their financial support. Furthermore Willy May from the Danish Climate Center, Danish meteorological Institute are acknowledge for providing us the ECHAM5 climate data.

Edited by: S. Galmarini

\section{References}

Brandt, J., Silver, J. D., Frohn, L. M., Geels, C., Gross, A., Hansen, A. B., Hansen, K. M., Hedegaard, G. B., Skjøth, C. A., Villadsen, H., Zare, A., and Christensen, J. H.: An integrated model study for Europe and North America using the Danish Eulerian Hemispheric Model with focus on intercontinental transport of air pollution, Atmos. Environ., 53, 156-176, 2012.

Christensen, J. H.: The Danish Eulerian Hemispheric Model - A three-dimensional air pollution model used for the Arctic, Atmos. Environ., 31, 4169-4191, 1997.

Clarke, L., Edmonds, J., Jacoby, H., Pitcher, H., Reilly, J., and Richels, R.: Synthesis and Assessment Product 2.1 by the U.S. Climate Change Science Program and the Subcommittee on Global Change Research, subreport 2.1A, Department of Energy, Office of Biological and Environmental Research, Washington DC, USA, 154 pp., 2007.

Fowler, D., Amann, M., Anderson, R., Ashmore, M., Cox, P., M, M. D., Derwent, D., Grennfelt, P., Hewitt, N., Hov, Ø., Jenkin, M., Kelly, F., Liss, P., Pilling, M., Pyle, J., Slingo, J., and Stefenson, D.: Ground-level ozone in the 21st century: future trends, impacts and policy implications, Science Policy Report 15/08, Royal Soc., 148 pp., 2008.

Geels, C., Hansen, K. M., Christensen, J. H., Skjoth, C. A., Ellermann, T., Hedegaard, G. B., Hertel, O., Frohn, L. M., Gross, A., Hansen, A. B., and Brandt, J.: Projected change in atmospheric nitrogen deposition to the Baltic Sea towards 2020, Atmos. Chem. Phys., 2615-2729, doi:10.5194/acp-12-2615-2012, 2012.

Guenther, A., Hewitt, C., Erickson, D., Fall, R., Geron, C., Graedel, T., Harley, P., Klinger, L., Lerdau, M., McKay, W., Pierce, T., Scholes, B., Steinbrecher, R., Tallamraju, R., Taylor, J., and Zimmerman, P.: A Global-Model of Natural Volatile OrganicCompound Emissions, J. Geophys. Res., 100, 8873-8892, 1995.

Guenther, A., Karl, T., Harley, P., Wiedinmyer, C., Palmer, P. I., and Geron, C.: Estimates of global terrestrial isoprene emissions using MEGAN (Model of Emissions of Gases and Aerosols from Nature, Atmos. Chem. Phys., 6, 3181-3210, doi:10.5194/acp-63181-2006, 2006.
Hedegaard, G. B.: Impacts of Climate Change on Air Pollution Levels in the Northern Hemisphere, Technical report 240, National Environmental Research Institute, Aarhus University, Frederiksborgvej 399, P.O. Box 358, 4000 Roskilde, Denmark, www.dmu. $\mathrm{dk}, 2007$.

Hedegaard, G. B., Brandt, J., Christensen, J. H., Frohn, L. M., Geels, C., Hansen, K. M., and Stendel, M.: Impacts of climate change on air pollution levels in the Northern Hemisphere with special focus on Europe and the Arctic, Atmos. Chem. Phys., 8, 3337-3367, doi:10.5194/acp-8-3337-2008, 2008.

Hedegaard, G. B., Gross, A., Christensen, J. H., May, W., Skov, H., Geels, C., Hansen, K. M., and Brandt, J.: Modelling the impacts of climate change on tropospheric ozone over three centuries, Atmos. Chem. Phys. Discuss., 11, 6805-6843, doi:10.5194/acpd11-6805-2011, 2011.

Hedegaard, G. B., Christensen, J. H., Geels, C., Gross, A., May, K. M. H. W., Zare, A., and Brandt, J.: Effects of Changed Climate Conditions on Tropospheric Ozone over Three Centuries, Atmos. Climate Sci., 2, 546-561, doi:10.4236/acs.2012.24051, 2012.

Langner, J., Bergstrøm, R., and Foltescu, V.: Impact of climate change on surface ozone and deposition of sulphur and nitrogen in Europe, Atmos. Environ., 39, 1129-1141, 2005.

Marsland, S. J., Haak, H., Jungclaus, J. H., Latif, M., and Roske, F.: The Max-Planck-Institute global ocean/sea ice model with orthogonal curvilinear coordinates, Ocean Model., 5, 91-127, 2003.

May, W.: Climatic changes associated with a global 2 degrees Cstabilization scenario simulated by the ECHAM5/MPI-OM coupled climate model, Clim. Dynam., 31, 283-313, 2008.

Meehl, G. A., Stocker, T. F., Collins, W. D., Friedlingstein, P., Gaye, A. T., Gregory, J. M., Kitoh, A., Knutti, R., Murphy, J. M., Noda, A., Raper, S. C. B., Watterson, I. G., Weaver, A. J., and Zhao, Z.-C.: Climate Change 2007: The Physical Science Basis, contribution of working group $\mathrm{i}$ to the fourth assessment report of the intergovernmental panel on climate change Global Climate Projections, 747-846, Cambridge University Press, Cambridge, UK and New York, NY, USA, 2007.

Murazaki, K. and Hess, P.: How does climate change contribute to surface ozone change over the United States, J. Geophys. Res., 111, D05301, 10.1029/2005JD005873, 2006.

Nakicenovic, N., Alcamo, J., Davis, G., de Vries, B., Fenhann, J., Gaffin, S., Gregory, K., Grübler, A., Jung, T., Kram, T., Rovere, E. L., Michaelis, L., Mori, S., Morita, T., Pepper, W., Pitcher, H., Price, L., Riahi, K., Roehrl, A., Rogner, H.-H., Sankovski, A., Schlesinger, M., Shukla, P., Smith, S., Swart, R., van Rooijen, S., Victor, N., and Dadi, Z.: Special Report on Emission Scenarios: a special report of Working Group III of the Intergovernmental Panel on Climate Change, Cambridge University Press, New York, NY, USA, 2000.

Pachauri, R. K. and Reisinger, A. (Eds.): Climate Change 2007: Synthesis Report, Contribution of working group I, II and III to the fourth assessment report of the Intergovernmental Panel on Climate Change, IPCC, 2007.

Pye, H. O. T., Liao, H., Mickley, L. J., Jacob, D. J., and Henze, D. K.: Effects of changes in climate and emissions on future sulfate-nitrate-ammonium aerosol levels in the United States, J. Geophys. Res., 114, 1-18, doi:10.1029/2008JD010701, 2009.

Racherla, P. N. and Adams, P. J.: U.S. ozone air quality under changing climate and antropogenic emissions, Environ Sci. 
Technol., 43, 571-577, 2009.

Roeckner, E., Bauml, G., Bonaventura, L., Brokopf, R., Esch, M., Giorgetta, M., Hagemann, S., Kirchner, I., Kornblueh, L., Manzini, E., Rhodin, A., Schlese, U., Schulzweida, U., and Tompkins, A.: The atmospheric general circulation model ECHAM5, Part I., Report 249, Max-Planck-Institute für Meteorologie, Hamburg, Germany, 2003.

Roeckner, E., Brokopf, R., Esch, M., Giorgetta, M., Hagemann, S., Kornblueh, L. Manzini, E., Schlese, U., and Schulzweida, U.: Sensitivity of simulated climate to horizontal and vertical resolution in the ECHAM5 atmosphere model, J. Climate, 19, 37713791, 2006.

Smith, S. and Wigley, T.: Multi-Gas Forcing Stabilization with the MiniCAM, Energy Journal, Special issue, 373-391, 2006.

Spiegel, M. R.: Theory and problems of statistics, Schaums Outline Series, McGraw-Hill, secound edn., 1992.

Tagaris, E., Manomaiphiboon, K., Liao, K.-J., Leung, L. R., Woo, J.-H., He, S., Amar, P., and Russel, A. G.: Impacts of global climate change and emissions on regional ozone and fine particulate matter concentrations over the United States, J. Geophys. Res., 12, 1-11, doi:10.1029/2006JD008262, 2007.
Wilkening, K.: Science and International Environmental Nonregimes: The Case of Arctic Haze, Rev. Policy Res., 28, 125148,2011

Wise, M. A., Calvin, K. V., Thomson, A., Clarke, L. E., BondLamberty, B., Sands, R. D., Smith, S. J., Janetos, A. C., and Edmonds, J. A.: Implications of Limiting $\mathrm{CO}_{2}$ Concentrations for Land Use and Energy, Science, 324, 1183-1186, 2009.

Wu, S., Mickley, L. J., Jacob, D. J., Rind, D., and Streets, D. G.: Effects of 2000-2050 changes in climate and emissions on global tropospheric ozone and the policy-relevant background ozone in the United States, J. Geophys., 113, D18312, doi:10.1029/2007JD009639, 2008a.

Wu, S., Mickley, L. J., Leibensperger, E. M., Jacob, D. J., Rind, D., and Streets, D. G.: Effects of 2000-2050 global change on ozone air quality in the United States, J. Geophys. Res., 113, D06302, doi:10.1029/2007JD008917, 2008b.

Zare, A., Christensen, J. H., Irannejad, P., and Brandt, J.: Evaluation of two isoprene emission models for use in a longrange air pollution model, Atmos. Chem. Phys., 12, 7399-7412, doi:10.5294/acp-12-7399-2012, 2012. 